\title{
Hillendale thickened tailings storage facility - from project to closure
}

\author{
K Goss-Ross Independent Tailings Consultant, South Africa
}

\begin{abstract}
A thickened tailings storage solution was implemented at Hillendale Mine to manage ultra-fine clay tailings over a relatively short mine life project, in an environmentally sensitive setting. Constant performance monitoring and adapting to achieve the final mine plan requirement was key to the success of fine tailings management.
\end{abstract}

The closure plan for the tailings storage facility (TSF) allows for natural drainage of rainwater and sustainable agriculture. The up to $18 \mathrm{~m}$ thick fines deposit is currently being capped with a layer of sand. This allows unhindered access for agriculture, with sugar cane planting progressing.

The paper highlights lessons learned and successes achieved over the project duration.

\section{Introduction}

The Tronox Hillendale Mine is a heavy minerals sand mining operation located on the east coast of South Africa in the province of KwaZulu-Natal, near the town of Richards Bay. The mine was commissioned in April 2001 and production stopped by the end of 2013, with rehabilitation still in progress. A new mine is being developed at Fairbreeze, which is located south of the town of Mtunzini (Figure 1).

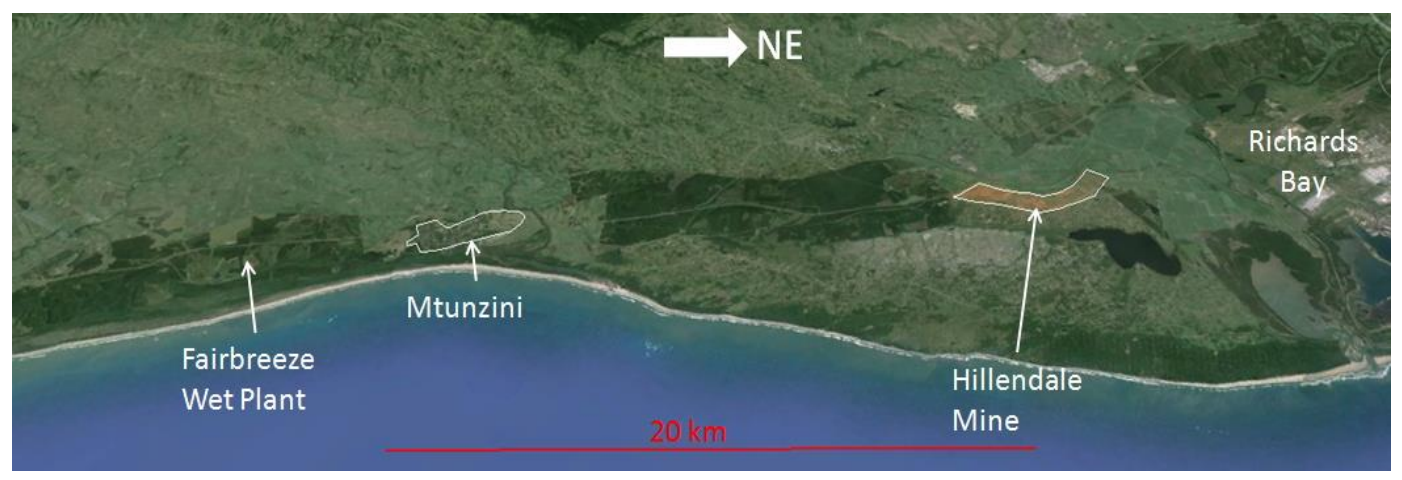

Figure 1 Location of Fairbreeze Mine relative to Hillendale Mine

The process consists of hydraulic mining and recovery of heavy mineral concentrate in a spiral concentrator. The ore is de-slimed by means of cyclones to improve mineral recovery on the spirals. Cyclone overflow is thickened and pumped as thickened tailings to a TSF, where it is managed by means of a rotational thin layer deposition and solar drying process.

Fines management was challenging at Hillendale due to the high proportion of clay ultra-fines (23\% of the ore). Fines are defined as particles finer than $45 \mu \mathrm{m}$, which is a typical mineral sands criterion. In addition, the available TSF site presented significant geotechnical challenges, being located within a flood plain.

Rainfall and evaporation are highest in summer. Annual rainfall is 1,200 mm/year and A-pan evaporation is $1,948 \mathrm{~mm} /$ year. 


\section{$2 \quad$ Clay fines properties}

The particle-size distribution (PSD) of typical sand tailings as well as the clay fines tailings as determined by hydrometer and laser diffraction method (Malvern) is given in Figure 2. The difference in fines particle-size distribution is as a result of the dispersant (Calgon) used in the hydrometer method, while only mechanical energy was used in the Malvern analysis. The hydrometer curve probably represents the most dispersed state of the clay, while the Malvern curve represents the likely particle-size distribution experienced in the process.

The process definition for fine tailings is those particles finer than $45 \mu \mathrm{m}$, but some sand tailings ( $+45 \mu \mathrm{m}$ ) report to the fines circuit. During the early years of operation, the percentage sand tailings in the fines was much higher, but was reduced to an average of about $10 \%$ through process improvements, which corresponds with the initial design.

The most abundant minerals in the fines are quartz, kaolinite, chlorite and hematite. The percentage clay mineral is in the order of $20 \%$ (semi-quantitative).

Typical Atterberg limits and geotechnical index properties of the fine tailings are given in Table 1.

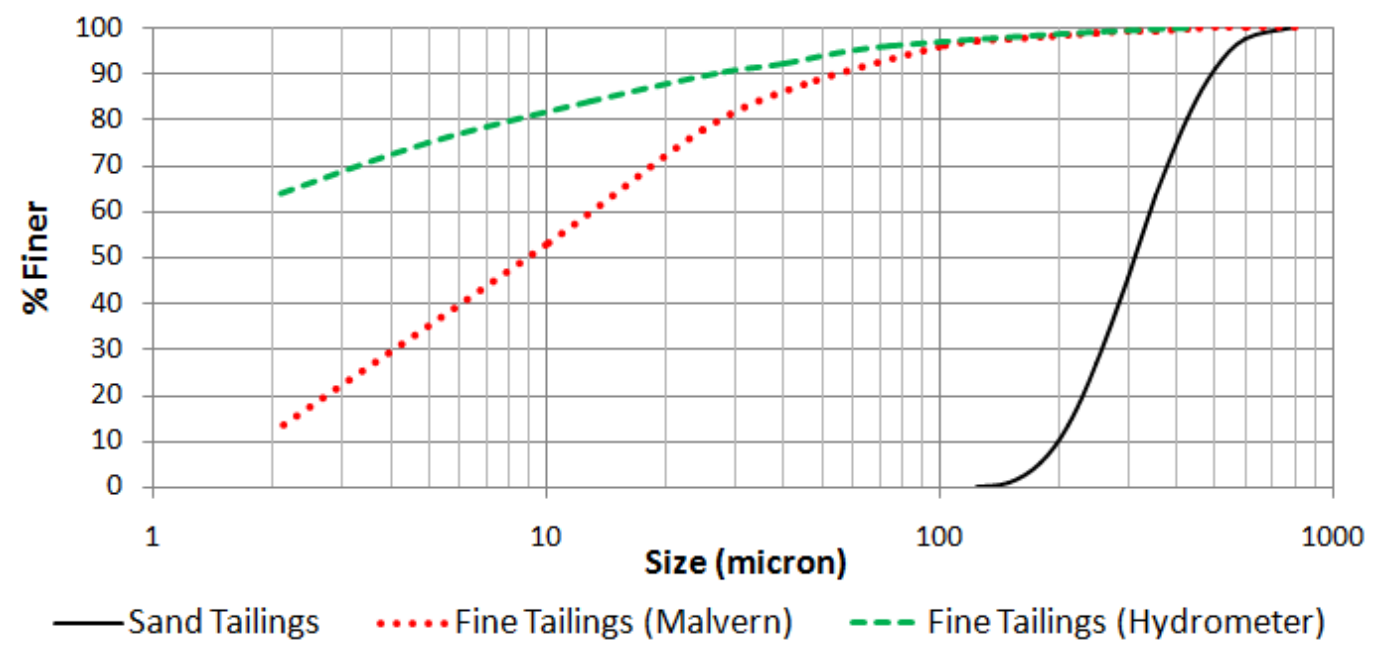

Figure 2 Typical particle-size distributions for fine and sand tailings

Table 1 Index properties for fine tailings

\begin{tabular}{cc}
\hline Liquid limit & 62 \\
Plastic limit & 36 \\
Plasticity index & 26 \\
Linear shrinkage & 13 \\
\% Clay (hydrometer method) & $63 \%$ \\
\% Silt (hydrometer method) & $28 \%$ \\
\% Sand & $10 \%$ \\
\hline
\end{tabular}

The fine tailings are shear sensitive, having a high yield stress at the thickener underflow discharge, but yield stress is rapidly reduced by the thickener underflow and positive displacement (PD) charge pumps.

Figure 3 shows the reduction in yield stress for a thickener underflow sample that was subjected to increasing periods of shear in a mixer. The rapid reduction is thought to be as a result of flocculent breakdown, as the particle size does not show major change with increased shear time. 
The reduction in yield stress is also visually apparent when comparing the fines slurry as it progresses through the thickener underflow and charge pumps (Figure 4), although there is also an effect of gland water dilution.

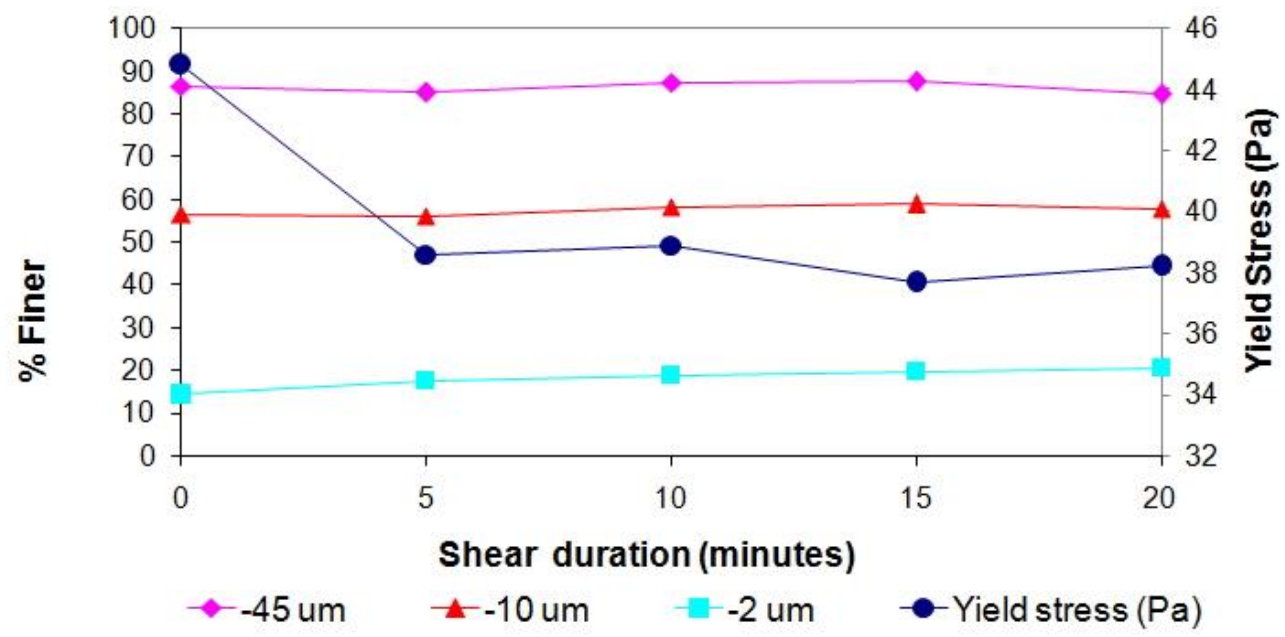

Figure 3 Shear sensitivity of fine tailings

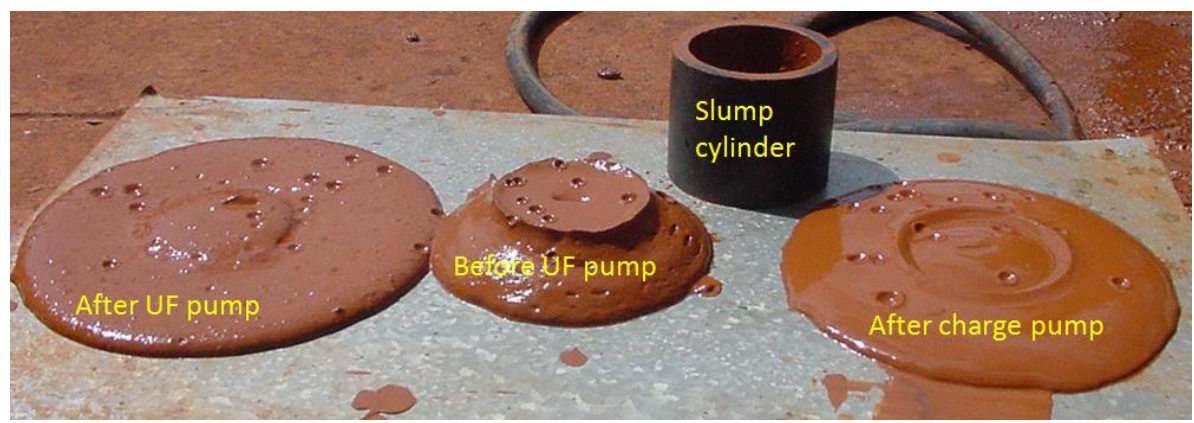

\section{Figure 4 Slump tests on fine tailings}

Figure 5 shows a typical yield stress versus density relationship for a sample taken from the charge pump discharge. The design density of $30 \%$ solids $(\mathrm{w} / \mathrm{w})$ was generally not well achieved, as can be seen in Figure 6, which depicts the average monthly density over the life-of-mine (LOM). This resulted in the PD pumps generally being under-utilised with pump pressures typically around $2.5 \mathrm{MPa}$ and peaking at $5 \mathrm{MPa}$, compared to an installed pressure of $8 \mathrm{MPa}$.

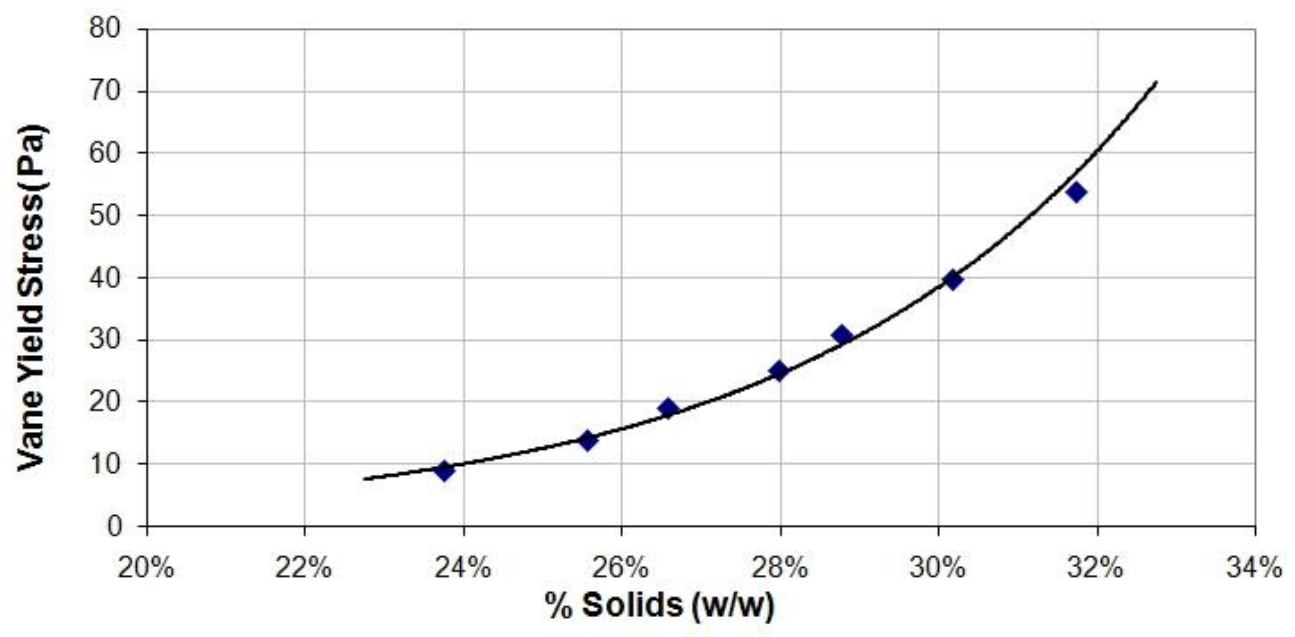

Figure 5 Yield stress versus density for a charge pump discharge fines sample 


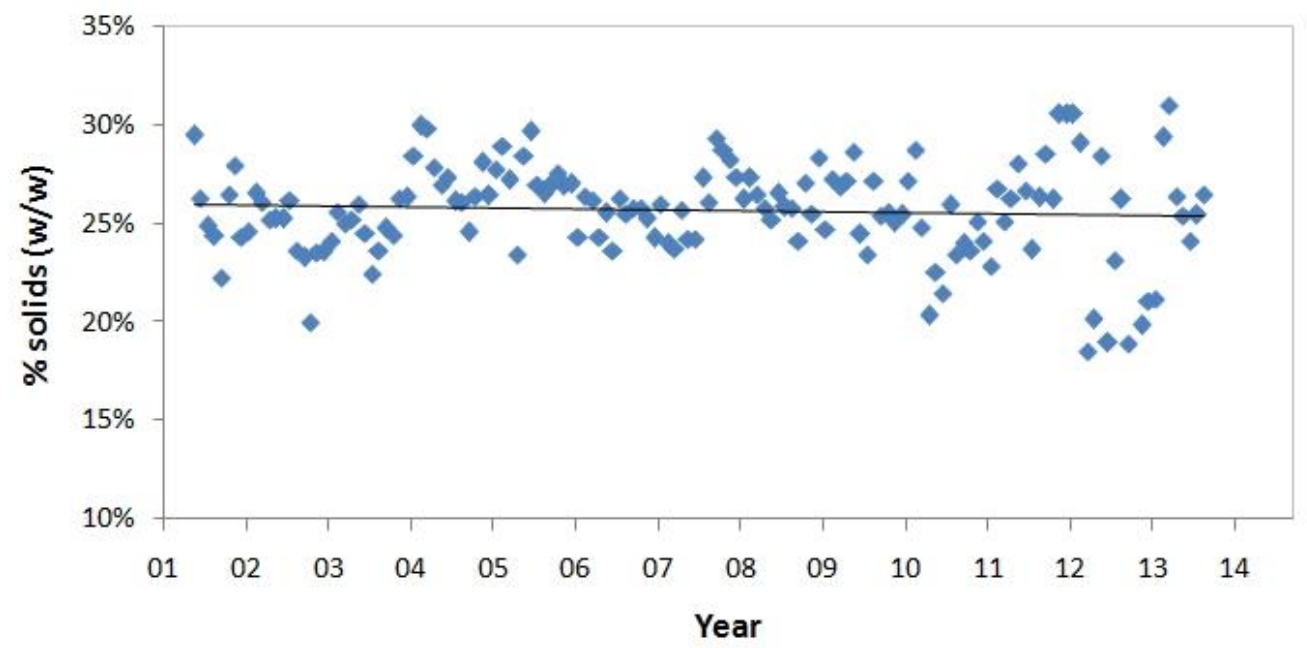

Figure 6 Average monthly fines density to the TSF

The gel point of the fine tailings was determined as $8.7 \%$ solids $(w / w)$.

\section{TSF design}

The TSF is situated on the Mhlatuze river flood plain, this being the only suitable flat area reasonably close to the dune shaped orebody. Starter walls of between $4-8 \mathrm{~m}$ in height had to be constructed to an elevation above the river flood level. The site presented significant construction challenges due to thick underlying layers of compressible peat. Staged construction and installation of vertical band drains up to $11 \mathrm{~m}$ depth were employed for construction of some of the embankments.

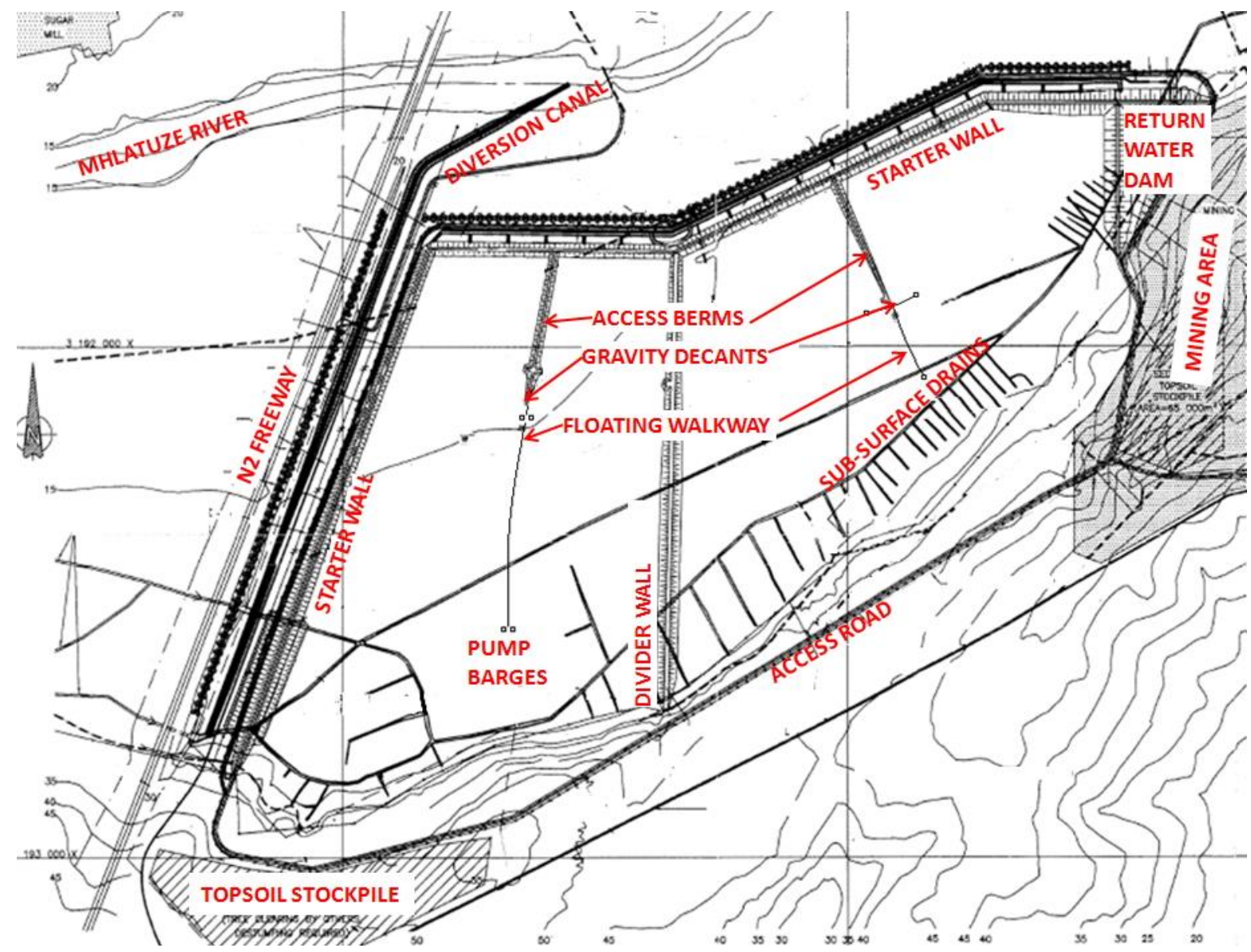

Figure 7 Plan layout of TSF at start-up 
The TSF occupies an area of 150 ha, with a fines deposition area of 133 ha. The deposition system consisted of 100 valves of $150 \mathrm{~mm}$ diameter spaced at $60 \mathrm{~m}$ centres along a $300 \mathrm{~mm}$ NB steel ring main around the TSF. Plug valves and rotating disc (knife gate) valves rated at $8 \mathrm{MPa}$ were installed to ensure that the full pressure capacity of the PD pumps could be used to open the pipeline in case of blockages. High-density polyethylene (HDPE) spigot pipes conveyed the slurry into the deposition basin.

The TSF was initially divided into two compartments due to a concern that beach angles will be too steep. The divider wall was replaced during construction with a row of vertical risers to reduce the required volume of earthfill while still maintaining the ability to have two separate drainage basins. The risers were later decommissioned after it was established that the division between the two basins could be maintained by deposition management from the ring main system.

The water decant system consists of a gravity emergency system and a pumped duty system. The gravity system consists of two pre-constructed ten metre high steel decant towers connected to outfall pipes discharging directly to the Mhlatuze river to the north of the TSF. It offers good flood protection but there has fortunately been no need to use them to date. Flanged openings on the decant towers were closed as the residue level in the dam increased. As the residue level approached the top of the initial towers, the towers were incrementally raised with flanged spool pieces.

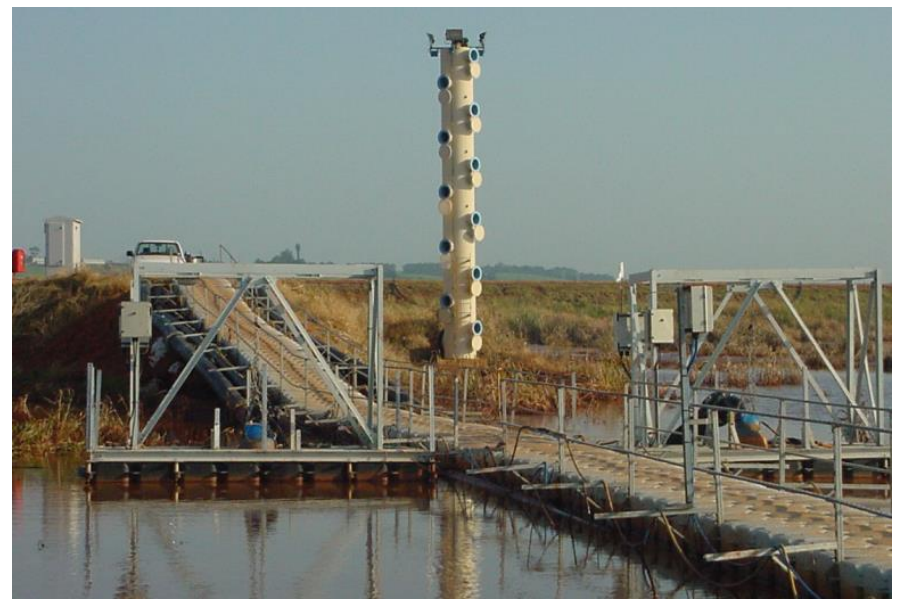

Figure 8 Decant system - stormwater decant tower and pump barges

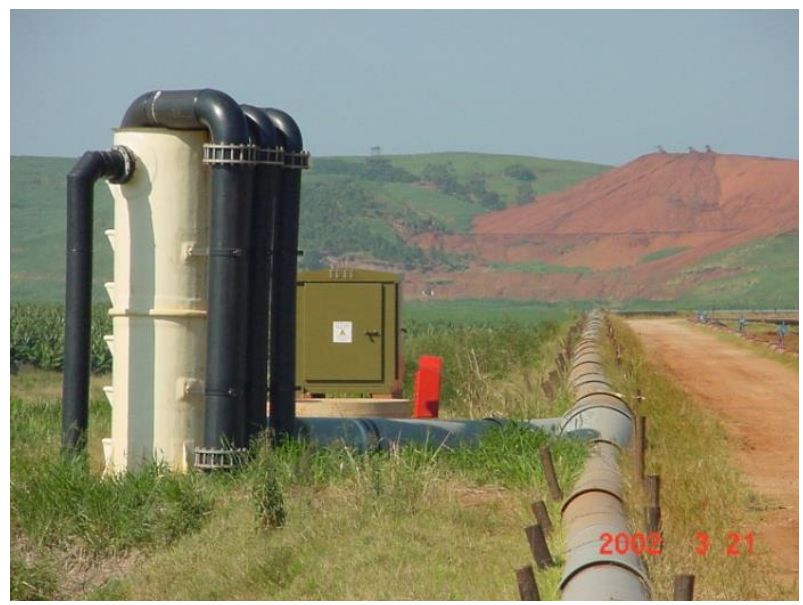

Figure 9 Barge pump delivery to header tank

Since the TSF is situated on a flood plain, the return water dam is located adjacent to and initially on the same elevation as the starter wall, which requires the water to be pumped to the return water dam. The decant pump system consists of submersible pumps on floating barges that deliver water to the return water dam via a header tank/gravity pipeline on the northern embankment of the TSF. The submersible 
pumps are installed in trays (shallow sumps) to skim clear water from the pool surface as the fines settle, making it possible to remove most of the water from the top of the fines. The pumping duty is made up of several smaller barge pumps, which were relocated as was required to manage the change in decant position. Access to the pumps and decant towers is by means of floating walkways from the northern perimeter wall of the TSF.

The HDPE lined return water dam has a capacity of $100,000 \mathrm{~m}^{3}$. Two vertically mounted Warman 8/6 pumps on barges were initially installed, but were later replaced with floating Flygt submersible pumps that supply land based Warman $8 / 6$ booster pumps. The modified system is much easier to maintain.

Based on the mine plan and estimated fine tailings properties, it was expected that a modest wall raise of $2.5 \mathrm{~m}$ would be required. The exact method of wall raise was left undecided pending observation of the actual performance of the TSF.

\section{$4 \quad$ Operating methodology}

Three deposition valves were opened at a time to deposit fines onto the TSF. Depending on the flow rate and the viscosity of the thickened slurry, it would be deposited through two or three of the opened valves simultaneously, which reduced the stream power and improved spreading of the thickened slurry on the beach. The thickened consistency of the slurry was critical to prevent segregation and to ensure that the slurry deposits as a homogeneous layer on the sloping beach (above water), to facilitate bleed and evaporative dewatering.

Fines slurry deposition was actively managed to ensure that the basin developed as planned and to maximise slurry coverage and drying efficiency across the complete surface area of the TSF. The ring main deposition system made it possible to utilise the complete drying area from very early on, in contrast to a central riser system where the deposition area develops with time as the stack grows in height.

Since the deepest part of the basin was on the southern side of the TSF against the dune, preferential deposition from the south allowed the decant pools to be migrated north to maximise storage volume against the dune. The pumps were progressively moved until the required operating decant position was attained. Figure 10 shows a section of surveyed profiles at different dates during the operating life of the TSF and approximate pump positions corresponding to each date.

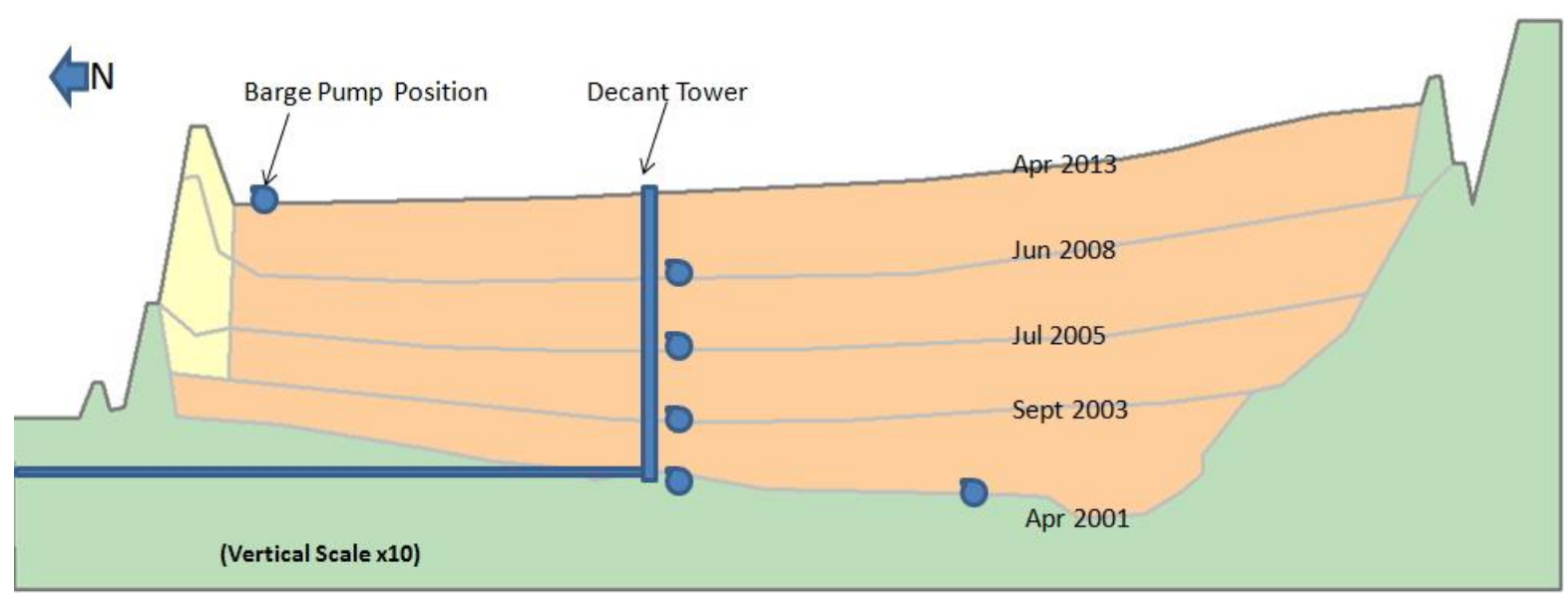

\section{Figure 10 Section at the east decant position showing changing beach profile}

The average residue thickness is $13.5 \mathrm{~m}$, but varies from $9 \mathrm{~m}$ on the north side to $18 \mathrm{~m}$ on the south.

The TSF was divided into ten sectors to simplify instructions, planning and record keeping. Deposition on a sector was usually completed before moving to a new sector. The valves were changed when the advancing front of depositing slurry at the particular valve position approached the decant area. The tonnage 
deposited per sector is a function of the area and deposited layer thickness, which is again a function of beach slope and beach surface condition and slurry rheology.

Initial high and varying sand content in the fines caused excessive valve wear and intermittent segregation at the deposition point, which resulted in poor deposition coverage and layers of sand that impaired drying. High sand content became less problematic as the process plant was improved. The thickener performance, however, did not live up to expectation and slurry density to the TSF remained lower than projected, despite extensive efforts to improve thickener performance.

The operating pump pressure of the PD pumps ranged from 2-3 MPa and occasionally went up as high as $5 \mathrm{MPa}$. This was notably lower than the design pressure but a good decision at the time given the available knowledge of the fines rheology and expectation of better thickener performance. A benefit of the PD pump system was lower gland water dilution as compared to a multiple stage centrifugal pump system. Later in the life of the mine the fines pipeline was eroded in local spots by sulphide reducing bacteria (SRB), and the operating pump pressure had to be limited to reduce the occurrence of pipe leaks.

The eventual beach slope is flatter than the design of $1: 80(\mathrm{~V}: \mathrm{H})$ and varies depending on the influence of the underlying surface and on deposition management. Where a virgin slope developed from the south, the slope ended up in the order of 1:150 ( $\mathrm{V}: \mathrm{H})$, and tends to be flatter close to the decant position (approximately 1:250 V:H). Initial expectations of a steeper beach slope were based on flume tests, which are now known to over-predict the beach slope.

The design cycle time was 21 days at a design layer thickness of $70 \mathrm{~mm}$. The actual cycle time varied per sector as more frequent deposition was done on the south side against the dune, where the final fine tailings thickness is almost double that on the north side. The average cycle time on the south was therefore much shorter than design and slightly longer than design on the north. Layer thickness was on average less than design, and tended to be the net result of all the other conditions at any particular time.

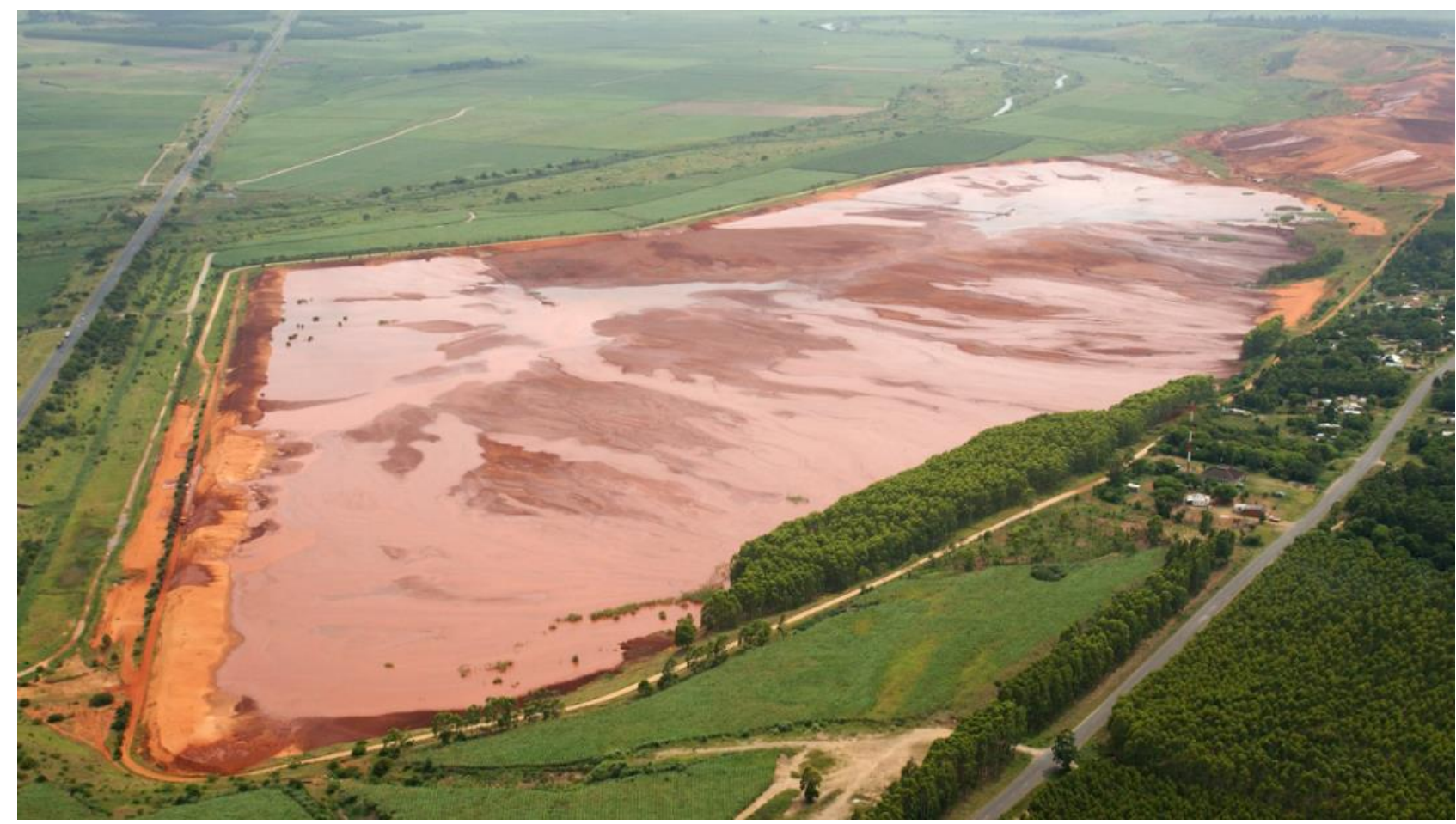

\section{Figure 11 Aerial photo of TSF taken in January 2007 from the southwest side}

\section{$5 \quad$ Performance tracking}

The stored dry density of the fines is dependent on self-weight consolidation on the beach above water and on evaporative drying. During the project phase, the storage dry density was estimated by means of 
laboratory drying tests and confirmed with pilot plant campaigns, where fines were deposited into paddocks at the expected cycle time.

The actual fines density was tracked by measuring the deposited tonnage with mass-flow instrumentation and calculating the deposited volume through survey. It was initially planned to track the deposited volume by means of a system of gauge poles, but this was soon abandoned in favour of a GPS on a hovercraft. The sand content $(+45 \mu \mathrm{m})$ was tracked in a daily composite sample.

Deposition management on the strip upstream of the starter walls was well managed to provide a good foundation for the intended upstream wall raise. Extensive sampling and shear vane testing was done to track the drying performance and strength gain.

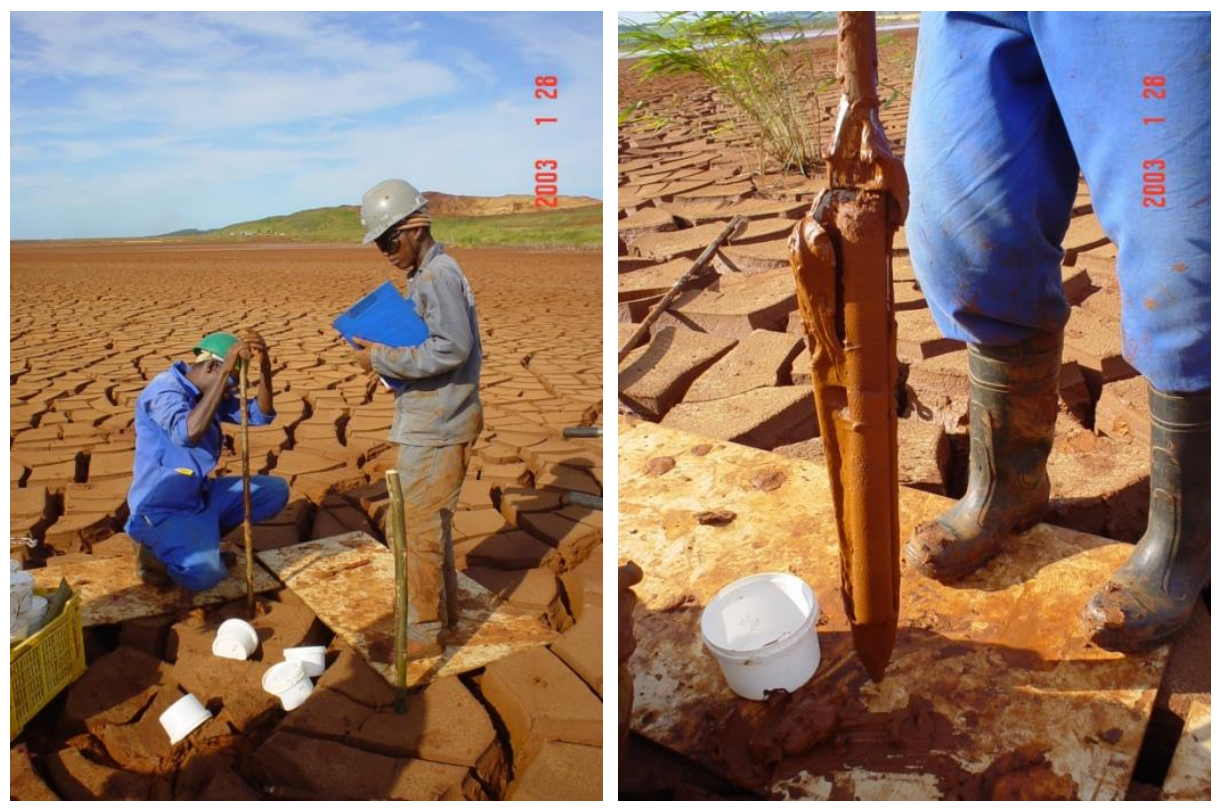

\section{Figure 12 Sampling and testing fine residue}

\section{$6 \quad$ Wall raising}

During design, it was not clear if the fine tailings properties will allow wall raising by means of the deposited fines. Since the anticipated wall raise was only $2.5 \mathrm{~m}$ high, this option was preferred. The drying and strength properties of the fine tailings were therefore intensively tracked during the first two years of operation to determine if the facility will be able to contain the anticipated tonnage of fine tailings at the forecasted dry density. Strict drying cycles were maintained against the upstream sides of the starter embankments to facilitate upstream wall raising. After a year it became apparent that the anticipated storage density will not be attained and at the lower density a higher wall raise will be required. Additionally, the lower realised density of the fine tailings offered lower strength, which could not support a future upstream wall raise. Revisions to the mine plan also increased the available ore and hence fines to manage. This necessitated the implementation of a separate sand pumping system for wall raising and widening of the wall.

The starter walls were placed at the maximum allowable limit and any widening had to be done by upstream method. An internal wall was constructed upstream of the starter walls and sand tailings were used to build an upstream foundation for the raised wall. Fine tailings that were already placed under the foundation of the raised wall were closely monitored to ensure that consolidation occurred at a sufficient rate to ensure stability.

The wall raising system was initially installed as an independent system with sand tailings loaded from the backfilled dune adjacent to the residue facility. It consisted of a four stage Warman 3/2 pump system, delivering to four $165 \mathrm{~mm}$ dewatering cyclones through a $180 \mathrm{~mm}$ HDPE pipeline at a pump rate of 
80 tonnes per hour. The cyclones were moved by hand in a 24 -hour operation. A second phase was introduced to supply selected low fines sand tailings from the spiral plant to the phase 1 pump system.

The final wall was raised nine metres above the starter wall.

PLANNED GEOMETRY

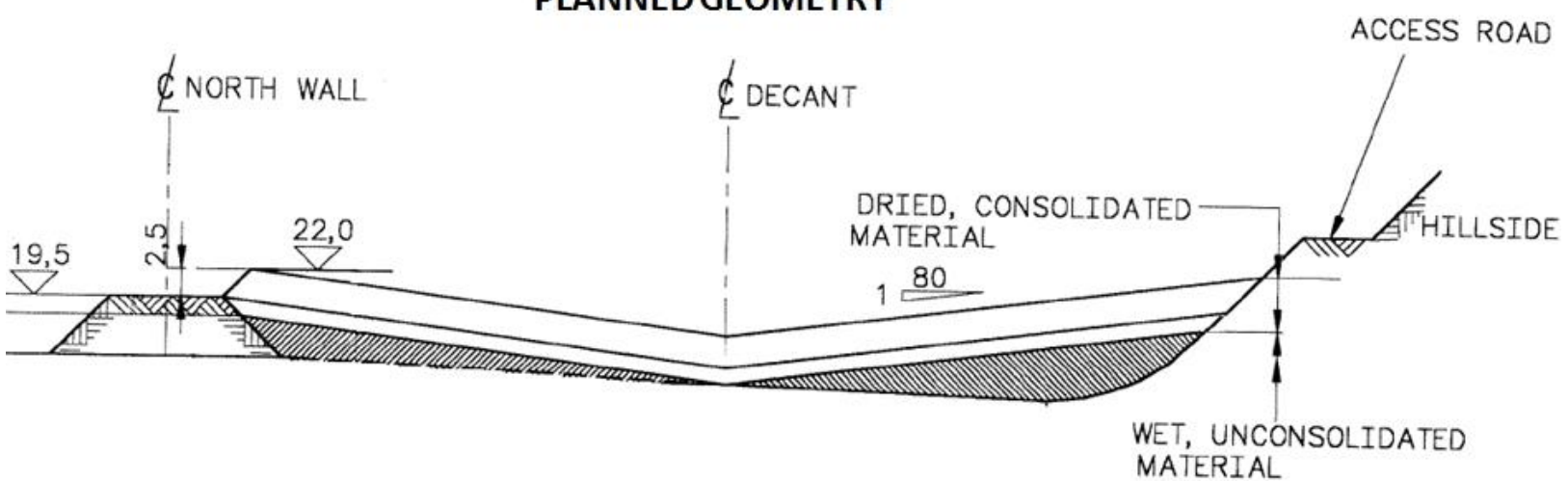

FINAL GEOMETRY

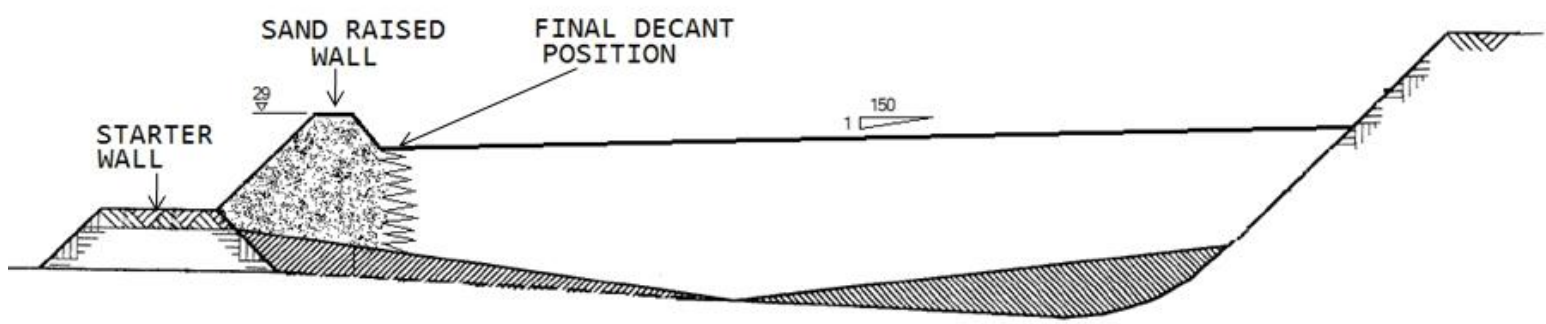

Figure 13 Schematic north-south section of initial planned and final wall geometry

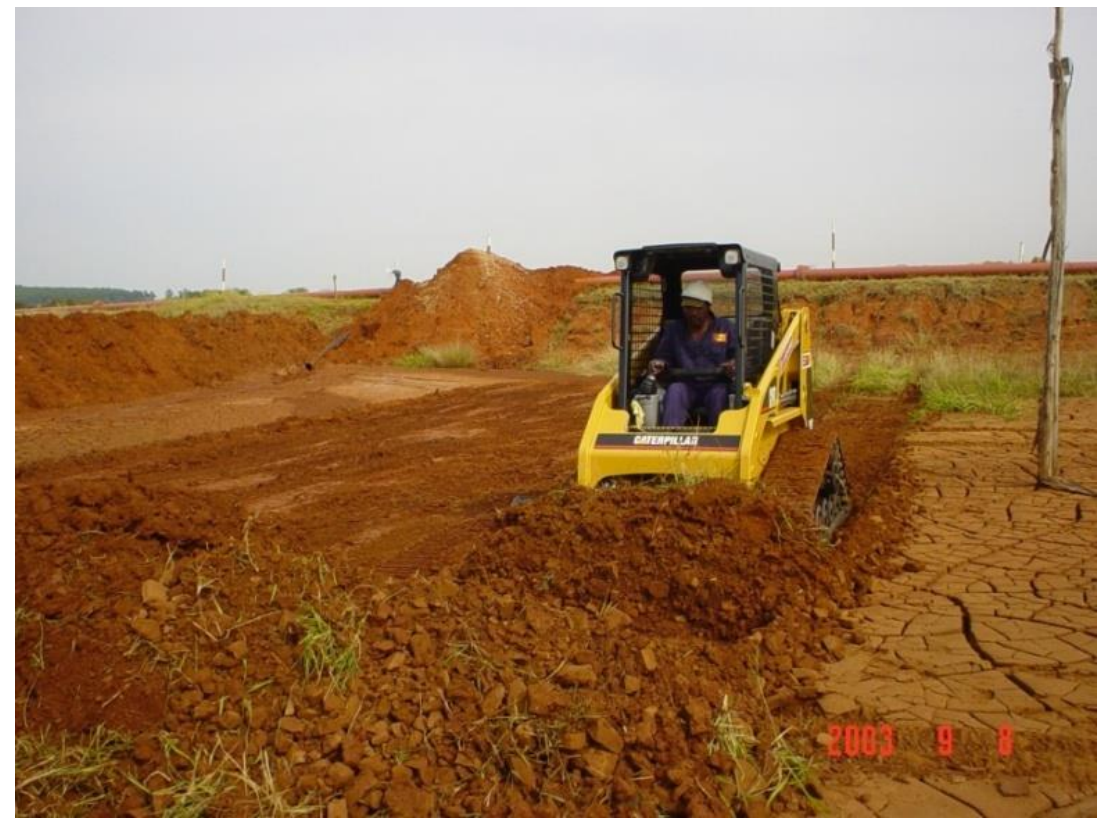

Figure 14 Internal wall being constructed for sand wall raising 


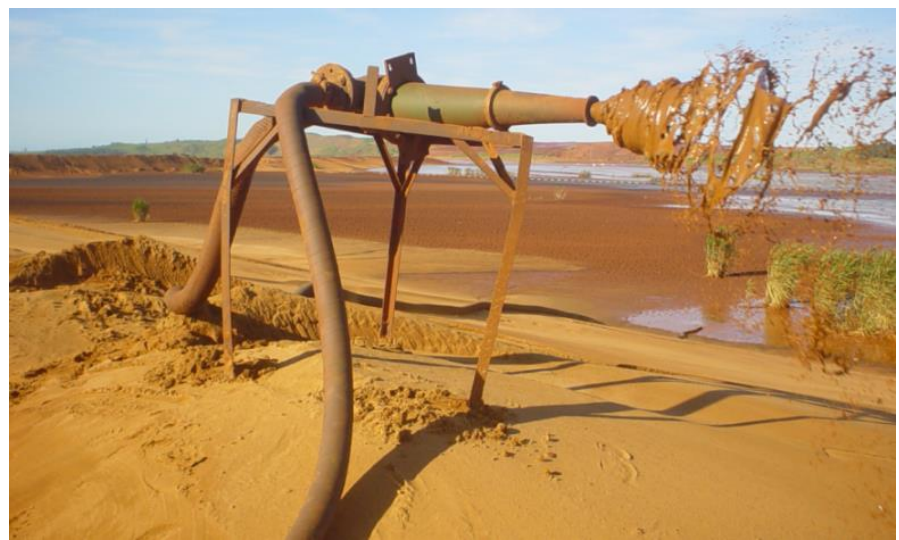

\section{Figure 15 Wall building cyclone}

\section{Rehabilitation}

During the last three years of production at Hillendale Mine, the fines deposition strategy was modified to progressively move the decant pumps further north, until the pools were situated adjacent to the wall. The freeboard was managed by raising the wall to always provide for the design flood water volume and the required additional freeboard.

When the mine approached the end of its life, the placement of a sand capping layer on the fines surface was initiated to allow access for farming equipment after rehabilitation. At the end of 2013, when production ceased, approximately 30 ha of the TSF were already capped. The capping is being completed by pumping sand tailings from the start-up stockpile.

The sand capping is placed by spraying sand onto the fines surface such that the bearing capacity of the fines material in the TSF is not exceeded; this requires an initial thin layer to be placed, followed with more layers to build the thickness up to between one to two metres. Vegetation that established on the surface (reeds and bulrushes) is beneficial to capping progress as it acts as reinforcement. The final sand capping layer supports all earthmoving, farming and utility vehicles on site and ensures that the TSF can be returned to its' intended land use of agriculture.

By the end of 2013, approximately 10 ha of sugar cane were already established on the capped area of the TSF. Silviculture is being investigated as an alternative crop, and Eucalyptus and Casuarina trees planted directly in the fine residue are performing well. This could prove to be a viable alternative rehabilitation strategy.

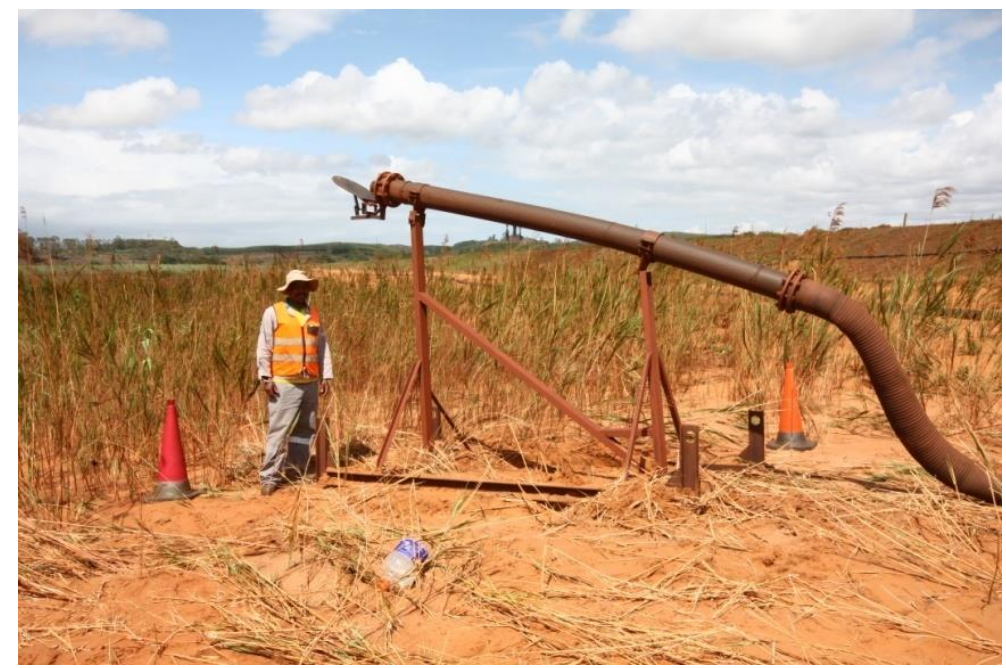

Figure 16 Sand capping gun 


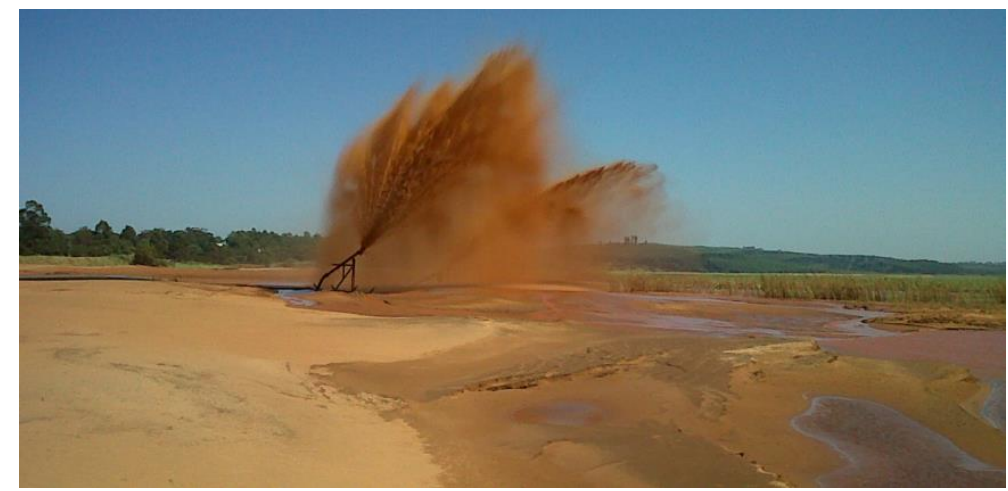

\section{Figure 17 Sand capping in progress}

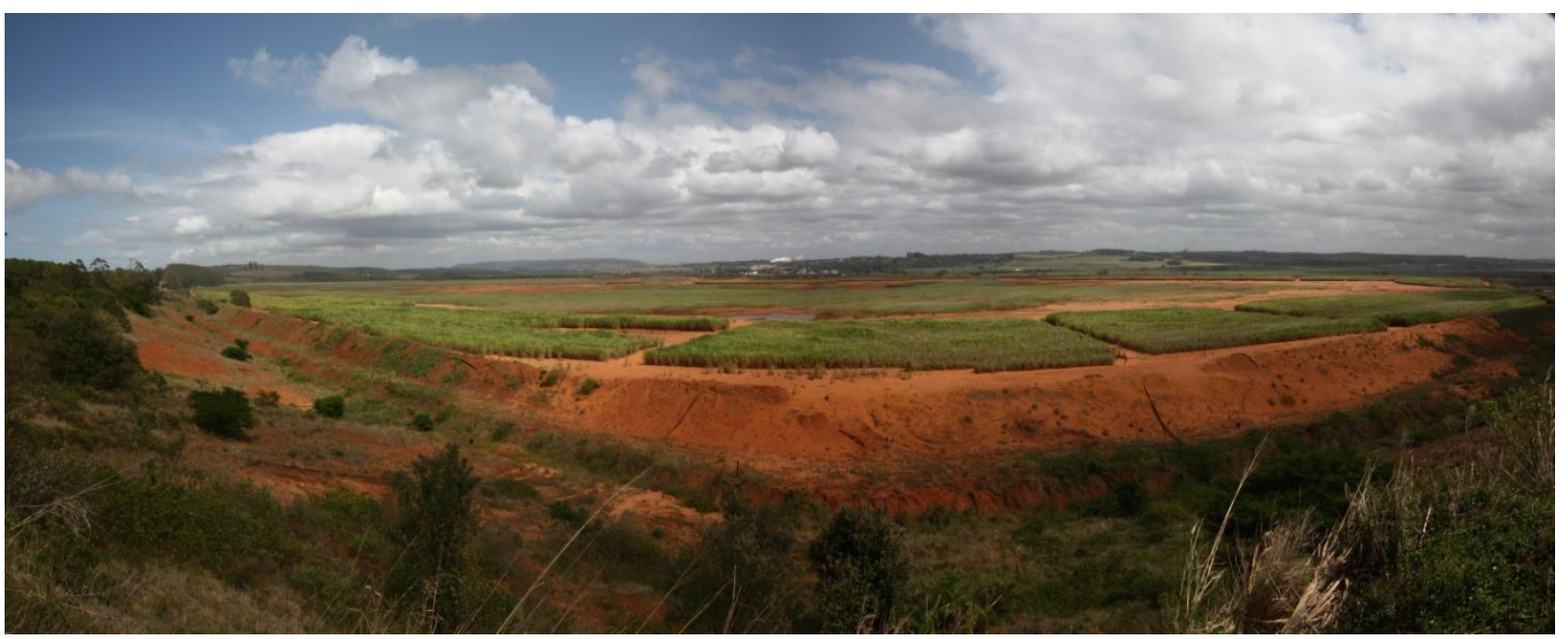

\section{Figure 18 TSF view from southeast showing sugarcane in foreground and reeds in} background

The raised walls are being planted with grass sods for erosion protection.

When the surface of the TSF has been capped and vegetation established on the top and side slopes, spillways will be installed to naturally decant rain water. The spillway inverts may require some adjustment while consolidation under the capping weight takes place.

\section{Conclusions}

The TSF design was continually adapted to ensure it fulfilled its required purpose, despite actual parameters not meeting design.

Active deposition management was used to offset challenges of low density and low yield stress slurry, and to create a suitable final beach profile for rehabilitation and closure.

Despite achieving lower fines storage density as compared to design, capping of the residue surface is being achieved successfully.

\section{Acknowledgement}

The author would like to thank TRONOX for granting permission to present this paper. 
